RESEARCH ARTICLE

\title{
PROCESS AND MINERALOGY OF VOLCANIC MATERIALS ON THE SOUTH SIDE OF THE OLD LAWU VOLCANO IN JAVA ISLAND
}

\author{
Mohammad Nurcholis $^{1 *}$, D. F. Yudiantoro ${ }^{2}$, D. Haryanto ${ }^{3}$, A. B. Dianputra ${ }^{1}$, and K. Aji ${ }^{4}$ \\ ${ }^{1}$ Study Program of Soil Science, Universitas Pembangunan Nasional "Veteran" Yogyakarta, Indonesia \\ ${ }^{2}$ Study Program of Geological Engineering, Universitas Pembangunan Nasional "Veteran" Yogyakarta \\ ${ }^{3}$ Study Program of Agrotechnology, Universitas Pembangunan Nasional "Veteran" Yogyakarta \\ ${ }^{4}$ Study Program of Soil Science, Gadjah Mada University, Indonesia \\ Submitted: 2019-01-20 Accepted: 2019-08-23
}

\begin{abstract}
Activities of Old Lawu volcano in the past resulted in various soil development in the south side of the volcano, especially in the area of the east side of Wonogiri and west side of Ponorogo, that located in the Java island. This area is also famous as herbal crops producer for raw materials of traditional herbal medicine industry. The purpose of this research is to identify the process of exposure of the parent materials in the Old Lawu volcanic environment, the development of the soil parent materials, and the mineralogy variation. Four Sites with different geological formation were observed, and each Site was selected for soil profile identification on the process of weathering of rocks. All layers of each profile were then sampled and then sand fraction of the fine earth particle was determined for the mineral type using $\mathrm{X}$-ray diffraction (XRD). The results showed that materials of the Old Lawu volcanic activity that was of quaternary period had sized material of gravel, sand, silt, and clay. These materials were then exposed and undergone the process of weathering, transportation, and sedimentation according to the landform at that period. The development of soil as geoheritage in this region was influenced by the material size, landform, and settling process. There are four typologies of the environment on the soil development at the present study, there are: (1) Soil that developed in the inter-fluvial basins is characterized by thick soil and a clear horizon differentiation process as a feature of maturity stage of soil development. (2) Soil developed on the slope of hill area is characterized by shallow in solum and it is in early-stage soil development. (3) Soil developed on the volcanic materials that were transported and sedimented in the river environment is characterized by the thick soil above the layered fine size parent material with a variety of color. (4) Soil developed on the tertiary breccia showed early soil development.
\end{abstract}

Keywords: Polysequence, Sand fraction, Soil development

How to Cite: Nurcholis, M., Yudiantoro, D. F., Haryanto, D., Dianputra, A. B., and Aji K. (2019). Process and Mineralogy of Volcanic Materials on the South Side of the Old Lawu Volcano in Java Island. Sains Tanah Journal of Soil Science and Agroclimatology, 16(2): 127-138 (doi: 10.20961/stjssa.v16i2.27118)

Permalink/DOI: http://dx.doi.org/10.20961/stjssa.v16i2.27118

\section{INTRODUCTION}

Volcanic activity is very important and is a key in the formation, development, and

\footnotetext{
* Corresponding Author :

Email:nurcholis@upnyk.ac.id
}

dynamics of soil, water cycle, fora, and fauna. Lawu volcano as a quaternary volcano on the border between central and eastern Java (van Bemmelen, 1949) as an active volcano has an important role in life in this region. The Old Lawu Volcano section is on the south side and covers the eastern part of Wonogiri and West 
Ponorogo regency. Both regencies are located in Java Island, while the administrative government, Wonogiri regency is in Central Java Province and Ponorogo regency in East Java Province.

The development of landform in the area of Old Lawu Volcano is very advanced with the occurrence of dissection results of erosion and sedimentation activities from ancient times. In connection with the soil development in Lawu volcano area is a geological heritage that must be studied, so that the benefits of the soil, rocks weathering and rocks that are the result of volcanism activities Lawu Volcano can be used sustainably (Soeria-Atmadja et al., 1994). Field observations show that the dynamics of landform and soil development are quite clear that there is an interesting link to be studied. The similar works had been carried out a study of the relationship between geological processes, the type of parent material, the nature of soil, and the mineralogy of weathering results and provides important information on the support of land as natural resources (Egli at al. 2001; Egli et al., 2003; Dahmsa et al., 2012; de Oliveira Jr et al., 2014; Doetterl et al., 2015). So that this research was aimed to study the development of soil as a result of the development of landform in Old Lawu Volcano area.

The utilization of this area is mostly as moorland and paddy fields, depending on the availability of water from irrigation canals. Dryland is mostly cultivated medicinal plants, so this area is very famous with the production of herbal medicine ingredients. Medicinal plants in producing quality materials require sufficient supply of nutrients, as well as in a variety of species. Other land uses are the mining of soil and rocks as material for hoarders and also for the bricks industry. Soil as an inherited of geological and pedological processes requires consideration of how soil use is a suitable resource to minimize the damage. The purpose of this study was to study the process of soil development, and the distribution of mineral in soils and parent material in the southern part of the Old Lawu (Figure 1).

\section{MATERIALS AND METHODS}

The study was conducted in the southern part of Lawu volcano, with research area in Wonogiri Regency east side to West side of Ponorogo Regency (Figure 1). The observed soil profile is a cliff slice that has been formed from soil use for material mining. The first profile with a depth of 250 $\mathrm{cm}$ was observed in the interfluvial valley of the volcanic remnant in the ancient volcanic complex in Ponorogo regency on the west side bordering the Wonogiri regency. A Profile 2 with a depth of $672 \mathrm{~cm}$ was observed in the Old Lawu Volcano area to the southwest of the first profile, which grew the ground in the early phase. The profile 3 with a depth of 999 $\mathrm{cm}$, was observed in the precipitation area formerly as river-side. The fourth profile in the south of the third profile, the profile has a depth of $100 \mathrm{~cm}$, which develops in Nglanggeran formation. Observation of the soil profile is aimed to identify the material diversity of soil constituents and the development of soil that has occurred. Observation of the soil layer and/or soil horizon formed was done soil sampling to analyze the mineralogy of the sand fraction using X-Ray Diffraction (XRD). Collecting sand fractions was done after cleaning of organic materials using $\mathrm{H}_{2} \mathrm{O}_{2}$ and splitting fractions of silt and clay. Interpretation of the mineral types read by XRD using mineralogy databases based on bulk analysis (Anthony et al., 2010). The peak intensity results from the XRD analysis were used to make a qualitative comparison of the identified minerals between each sample of each soil layer. The 
dominant minerals only identified in a coating are used to estimate the origin of the material deposition process.

\section{RESULTS}

\section{Old Lawu environment}

Lawu volcano is situated in the East part of the Java Island, and it is a boundary between Central Java and East Java Provinces. Lawu Volcano is one of the volcanoes located in the ring of fire as a result of the convergent boundary between the India-Australia plate to the south and Eurasian continental plate from the north which forms the eastern Sunda volcanic arc, a subduction-related feature that developed.

The southern Lawu Volcano complex has a very complex environment. Within this region, there is a residual tertiary volcano and called Ancient Volcano, which is suspected as a volcanic neck. On the south and southwest side of Old Lawu, there are volcanic breccias of Nglanggran and claystone of Dayakan formation (Figure 1).

Old Lawu volcano is physiographically located in the central depression zone of Solo Zone and is in transition between Western and Eastern Java (van Bemmelen, 1949). In the Volcanic/Magmatic Arcs of Java map, Old Lawu Volcano as quaternary volcano (SoeriaAtmadja et al., 1994, Setijadji, 2010). Old Lawu Volcano is an active volcano in the quaternary period, with the last eruption was interpreted happened on the Holocene epoch (van Bemmelen, 1949). The development of Young Lawu leads northward towards Sarangan, Cemorosewu, Tawangmangu, SoloKaranganyar road (Hartono, 1994).
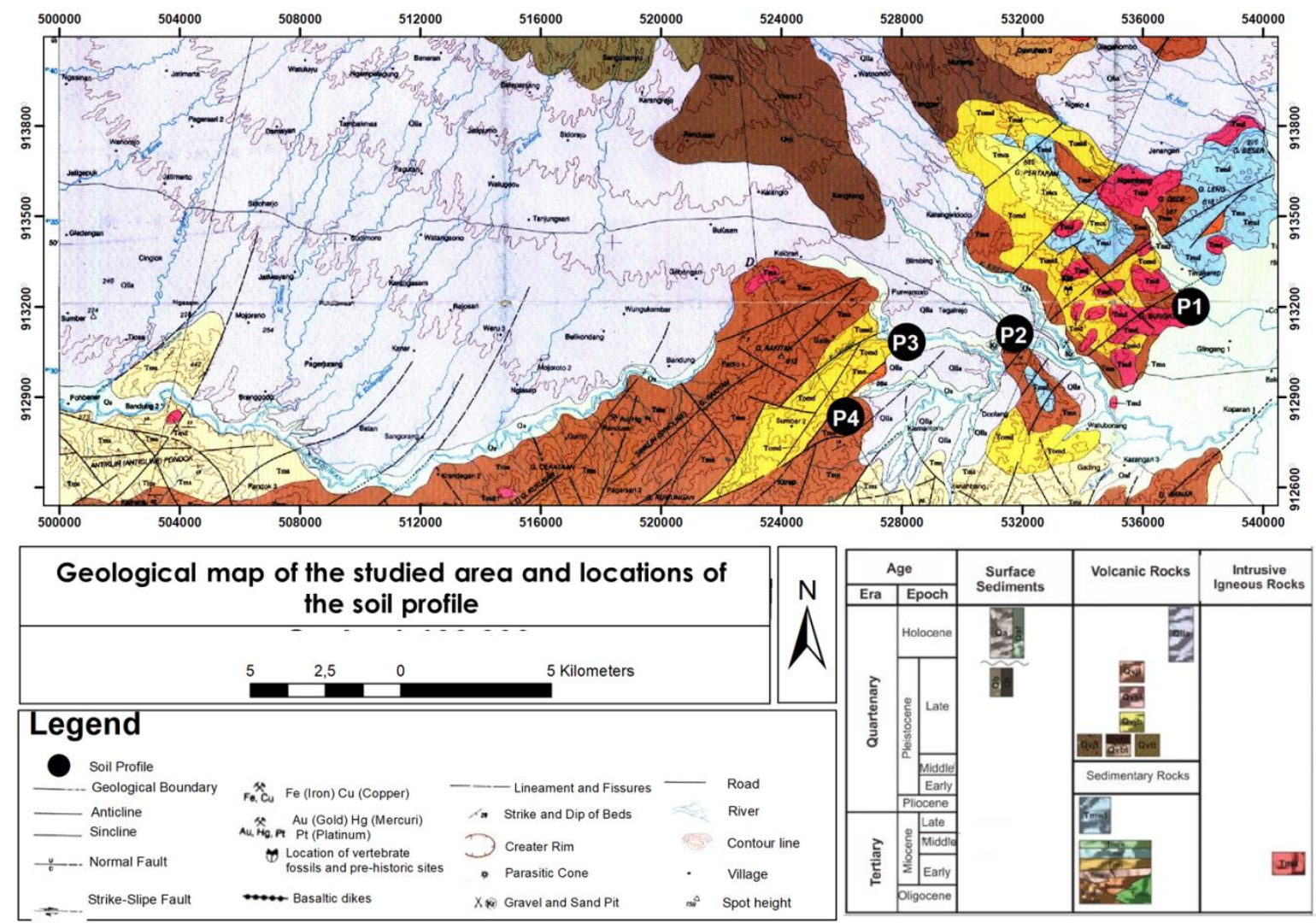

Figure 1. Regional Geological Map of the south side of the Old Lawu Volcano. Locations of the soil profiles are $P_{1}, P_{2}, P_{3}$, and $P_{4}$.

Source: Systematic Geological map of Indonesia, Quadrangle Ponorogo 1508-1, Scale 1:100.000 
Lawu volcano is a strato/composite type of volcano, therefore its type of eruption has to be the combination of effusive and explosive. The eruptions of Lawu volcano from old to young has also produced: (1) the pyroclastic flow deposits produced by eruptions due to the collapse of the lava dome, and (2) the ash-flow deposits alternating with the pumice drop deposits, resulting in a sub-Plinian eruption with magma composition estimated to be more acidic (Pramumijoyo et al., 2016).

\section{Soil morphology}

\section{Site 1}

The soil in Site 1 develops a recurrent process of sedimentation of volcanic material, and soil profile results show 8 layers. Morphologically it is identified that there are two types of parent materials from this soil, and have twice the soil formation (bisequence). This can be seen from the middle layer there is a $\mathrm{C} / \mathrm{R}$ horizon indicating the parent material of the soil from the upper sequence. Horizon A has a darker color than other horizons, this is because of the vegetation and rooting factors that exist in the area. The deeper the soil color profile is getting red color. This is thought to be the result of the accumulation of $\mathrm{Fe}$ and $\mathrm{Al}$ oxides. This soil texture is dominant clays and structured globular rounded with a class of medium structure but on the horizon $A$ has a crumb type structure and easily broken and crumbled when squeezed. On all horizons of consistency in wet conditions sticky and plastic. On horizon A, there were observed many plant roots which fine in size.

\section{Site 2}

The soil in Site 2 develops on a rather steep slope and has a thick solum with parent material of Old Lawu Volcano volcanic material (Figure 2.b). Field observations show that this profile may also undergo repeated parent materials deposition processes and any deposited material undergoes soil formation and produce a poly-sequent soil profile. In the material parent of this soil found fragments of coarse size and fine matrix. This soil has a dominant clay texture, with a subangular blocky structure, with a moderate structure class and with consistency of sticky and plastic.

\section{Site 3}

The soil in the Site 3 profile is in the morphology of the floodplain of the river at that time with the parent material consisting of a series of deposited alluvial materials (Figure 2.c). Basing the regional geological map then suspected deposited material is the result of an erosional process of volcanic material. The development of this soil is possible in any sedimentary sedimentation process over a relatively long period (Figure 2.a). This series of soil layers is suspected to have not undergone further pedogenesis processes since horizonization has not evolved clearly in every precipitation unit. However, pollen found in some coatings indicates the presence of vegetation that had grown at the time of deposition of the material. In this soil profile found fourteen layers with relatively diverse color. The texture of this soil is dominant in clay, and the structure is blocky and the consistency is slightly sticky and plastic.

\section{Site 4}

The soil in the soil 4 develops on the sediment breccias of volcanic material of Nglanggeran formation that has undergone weathering, with the slope of the land surface is quite steep (Figure 2.d). The andesite-basal rocks of the Nglanggeran formation are endMiocene (Sampurno \& Samodra, 1991). 

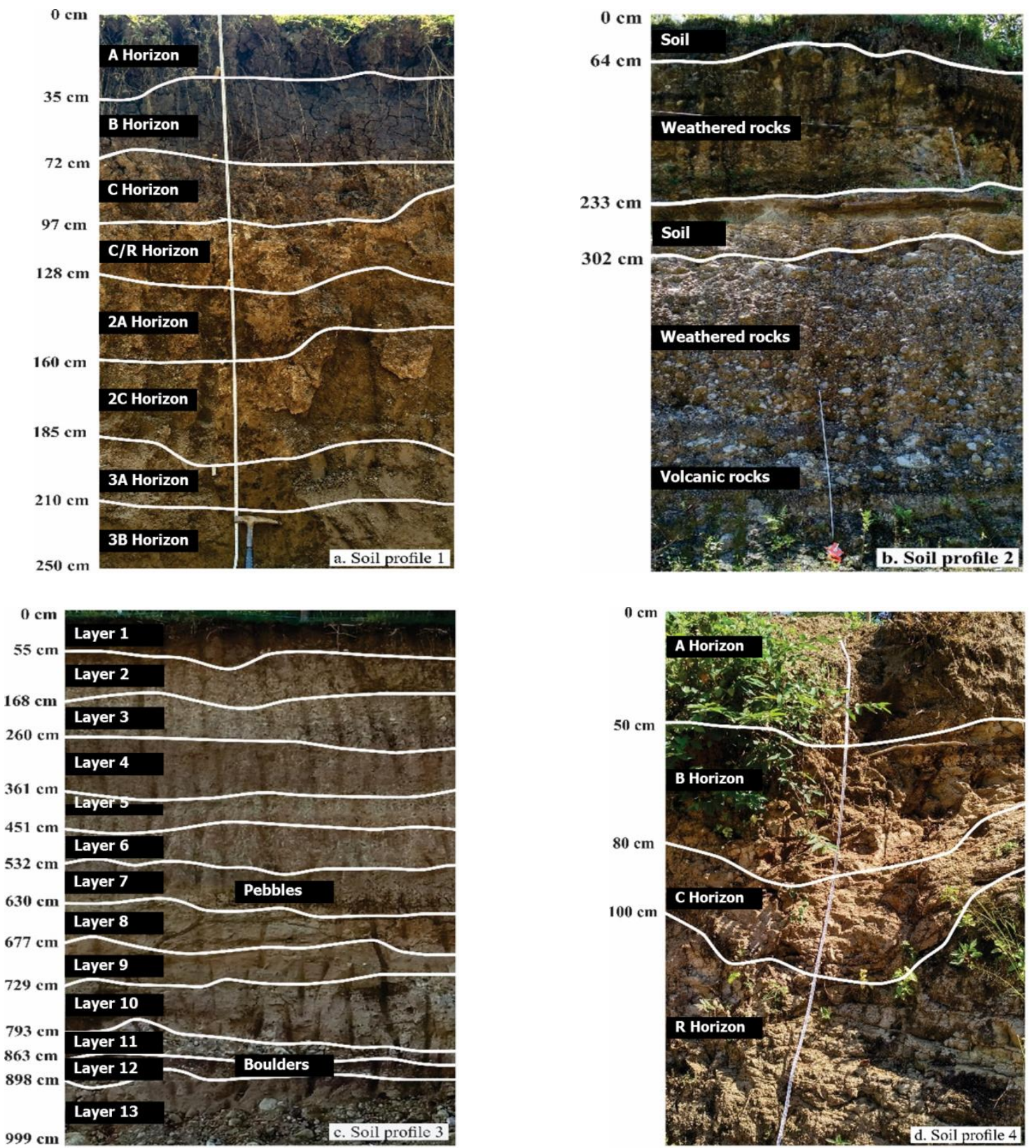

Figure 2. Four soil profiles developed from different parent materials were studied, soil developed from: a. Ancient Volcano, b. Old Lawu Volcano, c. Alluvial, and d. Nglanggeran Breccia

The texture of this soil is dominated by clay, the soil structure on the surface of the crumb is at the bottom of the subangular blocky, the consistency of the soil is slightly sticky. Vegetation at this location as found many herbs, especially medical crops as characteristics and famous of the Wonogiri Regency.

\section{Mineral distribution}

The results of the field observations and mineral identification of sand fraction from each layer of four profiles are presented in Table 1. XRD analysis results show Quartz minerals $\left(\mathrm{SiO}_{2}\right)$ on Profile 1 , and on soil profiles 3 and 4 are found in small quantities. However, in Profile 2 of the soil development of Old Lawu Volcano material that was no Quartz found in the sand fraction. The cristobalite mineral $\left(\mathrm{SiO}_{2}\right)$ was found to be uneven in almost every depth in all four soil profiles studied. The existence of cristobalite minerals was proposed as a result of crystallization of the final stages in volcanic 
Table 1. Mineral distribution on the sand fraction of the soil profiles

\begin{tabular}{|c|c|c|c|c|c|c|c|c|c|c|}
\hline \multirow{2}{*}{$\begin{array}{c}\text { No. } \\
\text { Profile }\end{array}$} & \multirow{2}{*}{$\begin{array}{l}\text { Depth } \\
\text { (cm) }\end{array}$} & \multicolumn{9}{|c|}{ Kind of mineral } \\
\hline & & Qtz & Crist & Albt & Augt & Andsn & Lab & Olvn & Leuco & Ribbt \\
\hline \multirow{8}{*}{1} & $0-35$ & +++ & +++ & +++ & - & +++ & - & - & +++ & ++++ \\
\hline & $35-72$ & +++ & - & - & ++++ & +++ & - & - & ++++ & ++++ \\
\hline & $72-97$ & +++ & - & - & - & ++++ & - & - & ++++ & - \\
\hline & $97-128$ & +++ & +++ & - & +++ & +++ & - & - & ++++ & ++++ \\
\hline & $128-160$ & +++ & - & +++ & +++ & - & - & - & - & ++++ \\
\hline & $160-185$ & +++ & - & - & +++ & ++++ & - & - & ++++ & ++++ \\
\hline & $185-210$ & +++ & +++ & - & - & ++++ & - & ++++ & - & ++++ \\
\hline & $210-250$ & +++ & +++ & - & - & +++ & - & - & - & - \\
\hline \multirow{4}{*}{2} & $0-64$ & - & +++ & - & +++ & +++ & - & - & - & - \\
\hline & $64-233$ & - & +++ & +++ & +++ & - & - & - & - & - \\
\hline & $233-302$ & - & +++ & +++ & - & - & - & - & - & - \\
\hline & $302-672$ & - & +++ & + & +++ & - & ++++ & - & - & - \\
\hline \multirow{14}{*}{3} & $0-55$ & + & - & - & - & - & - & - & - & - \\
\hline & $55-168$ & + & - & + & +++ & - & - & - & & - \\
\hline & $168-260$ & + & +++ & - & _ & - & +++ & - & - & - \\
\hline & $260-361$ & +++ & +++ & +++ & - & - & - & - & - & - \\
\hline & $361-451$ & +++ & +++ & - & - & - & ++++ & ++++ & - & - \\
\hline & $451-532$ & ++ & + & - & - & - & - & - & - & - \\
\hline & $532-630$ & + & - & ++++ & +++ & - & - & ++++ & - & - \\
\hline & $630-677$ & + & +++ & +++ & - & - & - & - & - & - \\
\hline & $677-729$ & + & +++ & ++++ & - & - & - & - & - & - \\
\hline & $729-793$ & + & + & - & - & + & - & - & - & - \\
\hline & $793-863$ & + & +++ & +++ & - & - & - & - & - & - \\
\hline & $863-898$ & +++ & +++ & +++ & - & - & - & ++++ & - & - \\
\hline & 898-933 & + & ++ & - & - & +++ & - & - & - & - \\
\hline & 933-999 & + & +++ & +++ & - & - & - & - & - & - \\
\hline \multirow{4}{*}{4} & $0-50$ & + & + & - & +++ & - & ++++ & - & - & - \\
\hline & $50-80$ & + & +++ & - & +++ & +++ & - & - & - & - \\
\hline & $80-100$ & + & - & - & ++++ & +++ & - & - & - & - \\
\hline & $>100$ & - & + & - & +++ & ++++ & - & - & - & - \\
\hline
\end{tabular}

Explanations:

- = none, $+=$ little, $++=$ medium, $+++=$ enough, $++++=$ many,

Qtz $=$ Quartz, Crist $=$ Cristobalite, Albt $=$ Albite, Augt $=$ Augite, Andsn $=$ Andesine, Lab $=$ Labradorite, Olvn $=$ Olivine, Leuco $=$ Leucophoenicite, Ribbt $=$ Ribbeite

rock (Ohba \& Nakagawa, 2002; Anthony et al., 2010). Mineral Albite $\left(\mathrm{Na}_{1.0-0: 9} \mathrm{CaO}: 0 ; 0: 1 \mathrm{Al}_{1: 0 ; 1: 1} \mathrm{Si}_{3 \cdot 0-2.9} \mathrm{O}_{8}\right)$ is found in the one profile in the surface layer and at a depth of $120-160 \mathrm{~cm}$. In the Profile 2, albite minerals profiles are found in $64-233 \mathrm{~cm}$ and 233-302 cm in depth. Albite minerals are present in the third profile in various coatings. The Augite $\left.\left\{(\mathrm{Ca}, \mathrm{Na})(\mathrm{Mg}, \mathrm{Fe} ; \mathrm{Al}, \mathrm{Ti})(\mathrm{Si}, \mathrm{Al})_{2} \mathrm{O}_{6}\right)\right\}$ minerals are present in the first, second and fourth profiles but in the third profile of the Augite minerals, there are only 55-168 and $532-560 \mathrm{~cm}$. Andesine minerals $\left\{(\mathrm{Na}, \mathrm{Ca})(\mathrm{Si}, \mathrm{Al}){ }_{4} \mathrm{O}_{8}\right\}$ are common in first and fourth profiles but only in the second and third profiles. The Labradorite minerals $\left(\mathrm{Na}_{0.5-0: 3} \mathrm{Ca}_{0.5-0.7} \mathrm{Al}_{1.5}\right.$ ${ }_{1.7} \mathrm{Si}_{2.5-2.3} \mathrm{O}_{8}$ ) are present in the second, third and fourth profiles but only in certain depths. The Olivine minerals $\left(\mathrm{Mg}^{2+}, \mathrm{Fe}_{2}{ }^{2+}\right)_{2} \mathrm{SiO}_{4}$ are in the first and third profiles but only to a certain depth. The Leucophoenicite mineral $\left(\mathrm{Mn}_{7}{ }^{2+}\right.$ $\left.\left(\mathrm{SiO}_{4}\right)_{3}(\mathrm{OH})_{2}\right)$ is present only in the first profile at a depth of $0-128 \mathrm{~cm}$ and again at a depth of 160-185 cm. Ribbeite minerals belonging to the Leucophoenicite group are present only in 
the first profile and dominate almost every depth but only at a depth of 72-97 cm and 210-250 cm no such minerals. Leucophoenicite and Ribbeite minerals as Mncontaining minerals are the results of formation in the final phase in the hydrothermal process (Anthony et al., 2010).

\section{DISCUSSION}

\section{Process on parent materials}

Java Island was built by volcanic activities in the tens of millions of years ago, which started from the seafloor. As for this volcanism, there was a meeting of the tectonic convergence of the Indian-Australian plate and Eurasian Continental plate at the southeastern boundary called Sundaland, which occurred during the early Tertiary period (Setijadji, 2010). The southern side of the Old Lawu Volcano area studied with ancient tertiary terrestrial volcano, Old Lawu volcanic material, alluvial, and volcanic breccia rocks (Figure 1) have a specific soil development model. The development of the soil in the remaining volcanic neck of ancient tertiary volcano gets periodic material deposition with the diversity of species and material size during deposition. Soil parent materials of the studied area were generally supported by serial volcanism activities in the past. There were obvious records for serial Ancient Volcano eruptions (Widodo, 2014), but remnants of volcanic and plutonic rocks are easily observed. Four profiles of the present studied might had probabilities of volcanic material depositions.

The profile 1 is dominated by Ancient Volcano materials, while it was also then buried by the following deposition from serial depositions later (Figure 2.a). Addition of following volcanic materials varying depends on the sizes and types of eruptions, and the composition of the elements of the magma it produces (Lowe, 2010). If the eruption is only as small type and it may add thin layers of volcanic tephra forming volcanic topdressing, and it gives beneficial effect on the elements to surface soils. It is clear that the profile shows the presence of lithologic discontinuities, or it is termed as multisequum profile (Dubroeucqa et al., 1998; Nanzyo, 2002).

The profile 2 is located in the Old Lawu area, it also shows serial depositions of volcanic material. The development of the soil in Old Lawu Volcanic material is characterized by a rather shallow solum, and there is a renewal of recurrent volcanic material, resulting in a polysequent soil profile (Figure 2.b). There is the usual phenomenon that has been developed earlier, and the development of volcanic soil periodically (Shoji \& Takahashi, 2002; Ugolini \& Dahlgren, 2002; Zehetner et al.,2002).

The profile 3 shows the occurrence of sedimentation that had been going on for a very long period of time with material transported from the results of the weathering of Old Lawu Volcanoes, as well as Ancient Volcanoes from the northern part (Figure 2.c). This happened because on the surface of the area there were many river streams flowing from the upstream to the downstream. Geomorphological characteristics change gradually from upstream to downstream, depending on the slope, relative topography, and the nature of the bedrock being traversed. In the upper reaches of the river system is dominated by the erosion process and produced sediment and was carried by the river currents.

In the area towards the downstream the process changes from erosion to sedimentation, and the results of sedimentation may form sediments especially in floodplains. The size of material which transported and sedimented depends on the nature and size of the material being 
transported, and the characteristics of the river flow. The existence of these differences regularly results in different sediment layers in terms of size and material properties of sediments. Therefore, erosion that occurs in nature especially geological erosion provides support for the dynamics of the geomorphological process (Négrel et al., 2013).

Profile 4 (Figure 2.d), based on the age of the material, breccia of Nglanggeran Formation is deposited at the tertiary era, and the presence of this formation is in the widearea along the southern mountain until Patuk Yogyakarta. Volcanic activity occurs during the formation of the Nglanggeran Formation in the Early to Middle Miocene (Surono, 2009; Surono \& Permana, 2011). This formation is composed of rocks in the form of polymict breccias, agglomerates, pyroclastic breccia, and lava. Ancient Volcano was active and it is identified also in the tertiary era (Figure 1). The Ancient Volcano is part of the Southern Mountains Zone which is composed of ancient Tertiary volcanic rocks. Research had been done, however the location of eruption center is still unknown (Widodo, 2014).

\section{Mineralogy of sand fraction}

Minerals in the sand fraction from the four soil profiles studied show that there was diversity systematically based on the original material and the processes that occur after its distribution on the earth's surface (Table 1). In profile 1 silica minerals were nominated by Quartz in each layer with a peak of $0.334 \mathrm{~nm}$. The existence of Cristobalite minerals (peak $0.405 \mathrm{~nm}$ ) was not detected at each layer. Mineral Quartz was not detected in profile 2, and only Cristobalite minerals were detected at each layer. These two minerals, namely Quartz and Cristobalite, are detected in profile 3 with enormous diversity. For profile 4 Quartz minerals were only slightly detected.
The occurrence of Quartz mineral (interplanar spacing of $0.343 \mathrm{~nm}$ ) is commonly found in hydrothermal veins, epithermal to alpine and also in hydrothermal metal deposits. This mineral is also common in residual mineral in soils and sediments. The occurrence of Cristobalite mineral is common in a latecrystallizing phase in basaltic to rhyolitic volcanic rocks, and also from acid-sulfate-type hydrothermal alteration of volcanic rocks (Ohba \& Nakagawa, 2002). Accordingly, Quartz mineral as a character of ancient volcanic material, while the Cristobalite mineral as a character for Old Lawu volcanic materials.

Abite mineral $(0.3196 \mathrm{~nm})$ was detected quite a lot in profile 2, and it was intermittently in profile 3 (Table 1). As for profile 4 this Augite mineral was not found. Albite is included in Feldspar group, plagioclase series which as a major constituent of granites rocks, basalts, and in hydrothermal and alpine veins, and also detrital and authigenic in sedimentary rocks. Andesine $(0.321 \mathrm{~nm})$ is detected in the profile 1 and 4 , minor in profile 2 and 4 . Andesine mineral is grouped Feldspar minerals and as plagioclase series, it is widespread in igneous rocks of intermediate silica content, as syenites and andesites, and also as detrital grains in sedimentary rocks. Labradorite and Olivine, both of which are same to Andesine and Albite in the Plagioclase series group, were not widely detected in the material studied.

Augite $(0.2994 \mathrm{~nm})$ as member of Pyroxene group is common in the profile 1,3 , and 4 , but minor in profile 3 (Table 1). Augite is essential in mafic igneous rocks and ultramafic rocks. Presence of this mineral is may in association with Orthoclase, Sanidine, Labradorite, Olivine, Leucite, Amphiboles, Pyroxenes. Study on the soil catenas on the west and north-east slopes of the Lawu Volcano showed that Augite minerals were 
also presence in the Old Lawu materials (Buurman \& Subardja, 1980). A small amount of the Augite mineral in profile 3 showed that during the process of material disintegration, transportation and sedimentation it caused advance weathering of Augite minerals, and these minerals are easily subjected to weathering in nature.

Profile 1 showed a presence specific Mn mineral of Leucophoenicite and Ribbeite $\left(\mathrm{Mn}^{2+} ; \mathrm{Mg}\right)_{5}\left(\mathrm{SiO}_{4}\right)_{2}(\mathrm{OH})_{2}$ with interplanar spacing of $0.18063 \mathrm{~nm}$, and $0.1796 \mathrm{~nm}$, respectively (Table 1 ). These minerals are classified as Leucophoenicite subgroup, and Humite group (Moore, 1967), and which are economic minerals if in the pure state and large quantities in mining ore (Kato \& Matsubara, 1994). Occurrence of Leucophoenicite mineral $\left(\mathrm{Mn}_{7}^{2+}\left(\mathrm{SiO}_{4}\right)_{3}(\mathrm{OH})_{2}\right)$ was reported in the volcanic environment of Franklin, New Jersey USA that was in a late-stage hydrothermal or contact zone mineral in veins (Anthony et al., 2010), and also in the sedimentary and metamorphic rocks (Dunn et al., 1988; Kato \& Matsubara, 1994).

The material deposition occurring in the floodplain beside the river produces a very thick alluvial material with clear coatings with high diversity (Figure 2.c). The development of the soil above the stone breccia Nglanggeran Formation did not produce deep solum with the initial level of development (Figure 2.d). In general, the results of chemical analysis and mineralogy of soil development in chronosequences can provide data support in processes that occur in landform formation (Egli et al., 2001; Egli et al., 2003) in the absence of major changes in the past caused by geological processes, such as tectonic activity in the form of faults and folds. While the study of the relationship between weathering and geomorphology in the Alpine mountains did not show such a thing because of the very large changes in the period of
3000-400 years in this location (Dahmsa et al., 2012).

Minerals identified in the sand fraction of the generally studied soils are dominated by Albite, Andesine, and Augite which are the source of $\mathrm{Na}$ and $\mathrm{Ca}$ elements (Table 1). Weathering of these minerals provides support for the chemical properties of the developing soil. Profile 3 which is the development of soil in alluvial materials indicates the diversity of minerals in various layers indicates a very diverse material source from the material in the field of this superior (Figure 2.c). Mineral types of Plagioclase Feldspar, such as Albite, Andesine, and Labradorites, and also Augite as Pyroxene mineral group that was detected in the authigenic soil parent materials in soil profiles indicated the characteristics of intermediary volcanic rocks of this area (Figure 3 ). While the profile 2 that was developed from a series of sedimentations in a very long time showed the variation of mineral types existence. The previous study showed that the Old Lawu materials were classified as hyperstheneaugite-andesite rocks (Tan \& van Schuylenborgh, 1959), also consisted of Quartz-containing andesitic conglomerates, breccias, and tuffs (Buurman \& Subardja, 1980).

A more in-depth study of the relationship between parent materials, primary and secondary minerals, and soil chemical properties in the studied sites strongly support the potential of the developing soil. The soil in the surrounding area studied is central to herbal medicine producers. Leucophoenicite and Ribbeite minerals as $\mathrm{Mn}$ form minerals which are the result of formation at the end of the hydrothermal environment provide additional information about the past environment in Ancient Volcano (Figure 1). 


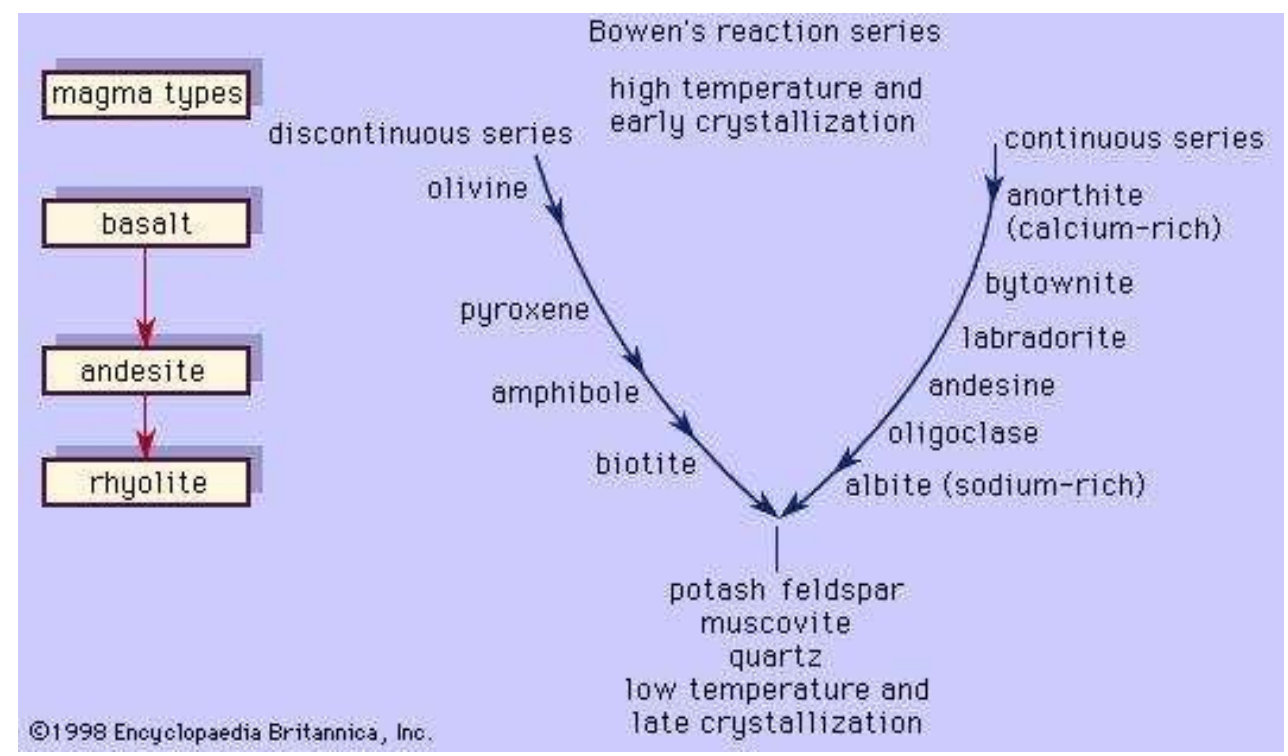

Figure 3. Bowen's reaction series (Encyclopedia Britannica, Inc)

The study of soil that develops from different parent materials in the surrounding of $\mathrm{Mt}$ Tangkubanprahu West Java showed differences in morphology, mineralogy, physical and chemical properties of different soils (Devnita et al., 2010).

\section{CONCLUSIONS AND SUGGESTION}

The process of the profile studied indicates that: the soil in the Profile 1 develops from the Ancient Volcanic parent material, the soil in the profile 2 developed from Old Lawu Volcano, the soil in the profile 3 developed from alluvial material with various sources, the profile 4 that soil developed from volcanic breccia. Minerals in the indicated sand fraction of soil may help to support the identification of soil materials from all soil profiles studied. In general, mineral types found in all soil profiles were classified in the intermediary group, and also materials were included in the intermediary rocks. Weatherable minerals such as Olivine was still identified in the lower layer in the soil profile developed from Ancient Volcanic materials and three layers in the profile 3 which developed on the Alluvial. Quartz mineral was not detected in the Old Lawu soil profile, and it is as a nature of this material.
Manganese minerals of Leucophoenicite and Ribbeite were as specific nature of soil profile developed from Tertiary Ancient Volcano.

According to the results of the present study, it is suggested that the detailed analysis of soil physical and chemical analysis on each horizon or layer of all soils is needed. Heavy metal elements in the soil are also needed to be analyzed that it may help for developing and improving the quality of herbal crops in this area.

\section{ACKNOWLEDGMENT}

This work is part of the main Research of the scheme of Applied Research of Flagship University or PTUPT funded by the Ministry of Research, Technology and Higher Education Republic of Indonesia for budget funds in 2018.

\section{REFERENCES}

Anthony, J. W., Bideaux, R. A., Bladh, K. W., \& Nichols, M. C. (2010). Handbook of Mineralogy. Chantilly, Virginia, USA: Mineralogical Society of America.

Buurman, P., \& Subardja. (1980). Soil Catenas on The West and North-East Slopes of The Lawu Volcano in East Java. In P. Buurman (Ed.), Red soils in Indonesia (pp. 49-68). Wageningen, Netherlands: 
Centre for Agricultural Publishing and Documentation.

Dahmsa, D., Favillib, F., Krebsc, R., \& Egli, M. (2012). Soil Weathering and Accumulation Rates of OxalateExtractable Phases Derived from Alpine Chronosequences of up to $1 \mathrm{Ma}$ in Age. Geomorphology, 151-152, 99-113.

de Oliveira Jr, J. C. de, Melo, V. F., Souza, L. C. P., \& da Rocha, H. O. (2014). Terrain Attributes and Spatial Distribution of Soil Mineralogical Attributes. Geoderma, 213, 214-225.

Devnita, R., Arifin, M., Salim, E. H., Sudradjat, A., Hudaya, R., \& van Ranst, E. (2010). Soils Developed on Volcanic Materials in West Java, Indonesia. International Journal of Arts and Sciences, 3(9), 180-192.

Doetterl, S., Cornelis, J. T., Six, J., Bodé, S., Opfergelt, S., Boeckx, P., \& van Oost, K. (2015). Soil Redistribution and Weathering Controlling the Fate of Geochemical and Physical Carbon Stabilization Mechanisms in Soils of an Eroding Landscape. Biogeosciences, 12, 1357-1371.

Dubroeucqa, D., Geissertb, D., \& Quantin, P. (1998). Weathering and Soil Forming Processes under Semi-Arid Conditions in Two Mexican Volcanic Ash Soils. Geoderma, 86(1-2), 99-122.

Dunn, P. J., Francis, C. A., \& Innes, J. (1988). A Mcgovernite-like Mineral and Leucophoenicite from the Kombat Mine, Namibia. American Mineralogist, 73(910), 1182-1185.

Egli, M., Fitze, P., \& Mirabella, A. (2001). Weathering and Evolution of Soils Formed on Granitic, Glacial Deposits: Results from Chronosequences of Swiss Alpine Environments. CATENA, 45(1), 19-47.

Egli, M., Mirabella, A., \& Fitze, P. (2003). Formation Rates of Smectites Derived from Two Holocene Chronosequences in the Swiss Alps. Geoderma, 117(1-2), 8198.

Hartono, U. (1994). The Petrology and Geochemistry of the Wilis and Lawu Volcanoes, East Java. University of Tasmania.
Kato, A., \& Matsubara, S. (1994). Ribbeite from the Kaso Mine, Kanuma City, Tochigi Prefecture, Japan. Mineralogical Journal, 17(2), 77-82.

Lowe, D. J. (2010). Quaternary Volcanism, Tephras, and Tephra-Derived Soils in New Zealand: an Introductory Review. In D. J. Lowe, V. E. Neall, M. Hedley, B. Clothier, \& A. Mackay (Eds.), Guidebook for Pre-conference North Island, New Zealand, Volcanoes to Oceans field tour (pp. 7-29). North Palmerston, New Zealand: Soil and Earth Sciences Occasional Publication No. 3, Massey Univ.

Moore, P. B. (1967). On Leucophoenicites: I. A Note on Form Developments. American Journal of Plant Physiology, 52(7-8), 1226-1232.

Nanzyo, M. (2002). Unique Properties of Volcanic Ash Soils. Global Environmental Research -English Edition-, 6(2), 99-112.

Négrel, P., Merly, C., Gourcy, L., Cerdan, O., Petelet-Giraud, E., Kralik, M., ... Vegter, J. (2013). Soil-Sediment-River Connections: Catchment Processes Delivering Pressures to River Catchments. In J. Brils, W. Brack, D. Müller-Grabherr, P. Négrel, \& J. E. Vermaat (Eds.), Risk-Informed Management of European River Basins. The Handbook of Environmental Chemistry Vol 29 (pp. 21-52). Berlin, Jerman: Springer.

Ohba, T., \& Nakagawa, M. (2002). Minerals in Volcanic Ash 2: Non-Magmatic Minerals. Environtmental -English Edition-, 6(2), 53-60.

Pramumijoyo, S., Harijoko, A., Setiawan, N. I., Freskl, Y. R., Priyambodo, E. R., Hapsari, Y. T., \& Handini, E. (2016). Stratigrafi Vulkanik Gunung Api Lawu, Jawa Timur. In Seminar Nasional Kebumian ke-9: Peran Penelitian IImu Kebumian dalam Pemberdayaan Masyarakat (pp. 558560). Yogyakarta, Indonesia: Department of Geology Engineering, UGM.

Sampurno, \& Samodra, H. (1991). Geologi Lembar Ponorogo, Jawa. Bandung, Infonesia: Pusat Penelitian dan Pengembangan Geologi Indonesia. 
Setijadji, L. D. (2010). Segmented Volcanic Arc and its Association with Geothermal Fields in Java Island, Indonesia. In World Geothermal Congress (pp. 1-12). Bali, Indonesia.

Shoji, S., \& Takahashi, T. (2002). Environmental and Agricultural Significance of Volcanic Ash Soils. Global Journal of Environmental Research, 6(2), 113-135.

Soeria-Atmadja, R., Maury, R. C., Bellon, H., Pringgoprawiro, H., Polve, M., \& Priadi, B. (1994). Tertiary Magmatic Belts in Java. Journal of Southeast Asian Earth Sciences, 9(1-2), 13-27.

Surono, S. (2009). Litostratigrafi Pegunungan Selatan Bagian Timur Daerah Istimewa Yogyakarta dan Jawa Tengah. Jurnal Geologi Dan Sumberdaya Mineral, 19(3), 209-221.

Surono, S., \& Permana, A. (2011). Litostratigraphic and Sedimentological Significants of Deepening Marine Sediments of the Sambipitu Formation Gunung Kidul Residence, Yogyakarta. Bulletin of the Marine Geology, 26(1), 15-30.
Tan, K. H., \& van Schuylenborgh, J. (1959). On the Classification and Genesis of Soil, Derived from Andesitic Volcanic Material under a Monsoon Climate. Netherlands Journal of Agricultural Science, 7(1), 4145.

Ugolini, F. C., \& Dahlgren, R. A. (2002). Soil Development in Volcanic Ash. Global Environmental Research -English Edition-, 6(2), 69-82.

van Bemmelen, R. W. (1949). The Geology of Indonesia (Vol. 1A). Belgia: The Hague: Martinus Nijhoff.

Widodo. (2014). Identifikasi Awal Gunung Api Purba Daerah Gunung Bungkus Kecamatan Badegan Kabupaten Ponorogo Jawa Timur. MTG, 4(2). Retrieved from http://jurnal.upnyk.ac.id/index.php/mtg /article/view/223

Zehetner, F., Miller, W. P., \& West, L. T. (2002). Pedogenesis of Volcanic Ash Soils in Andean Ecuado. Soil Science Society of America Journal, 67(6), 1797-1809. 